\title{
Hypertonic volume therapy: feasibility in the prevention and treatment of multiple organ failure and sepsis
}

\author{
Department of Surgery, Santa Casa School of Medicine, Institute for Anesthesiology, \\ University of Munich, Germany
}

\begin{abstract}
Small-volume resuscitation by means of bolus infusion of hypertonic saline solutions was first applied for the primary treatment of severe hemorrhagic and traumatic shock and promptly restored central hemodynamics and regional organ blood flow. Mechanisms of action are diverse - $i$. maintenance of high cardiac output (direct myocardial stimulation; increase in intravascular volume); ii. maintenance of peripheral arterial vasodilation (effect of hyperosmolality; plasma volume effect) and iii. reduction of tissue edema (shifting of tissue water along the osmotic gradient). These mechanisms promote the restoration of the severely impaired microcirculation frequently seen also in sepsis. Hypertonic volume therapy has been the object of several experimental studies of acute hyperdynamic endotoxemia, however, a greater number of clinical studies have to be developed for the better understanding of the positive, and perhaps hazardous, effects of small-volume resuscitation in sepsis and multiple organ failure. The aim of this paper is to review the concepts involving such solutions, and their potential use in treatment of profound hypovolemia and microcirculatory deterioration associated with sepsis and endotoxic shock.
\end{abstract}

UNITERMS: Sepsis. Multiple organ failure. Hypertonic solution. Shock.

\section{INTRODUCTION}

I njury is the leading cause of morbidity and mortality in both males and females under 45 years of age and the third cause in the general population, preceded only by cardiovascular diseases and cancer $(2,42)$. Efforts to reduce trauma deaths focus on the improvement of pre-

\section{Address for correspondence:}

Adhemar M. Pacheco Jr.

R. Martinico Prado, $90 /$ Ap. 133

São Paulo/SP - Brasil - CEP 01224-010 hospital care by rapid resuscitation from hypovolemia and systemic hypotension. Besides ventilatory assistance, primary resuscitation from severe trauma and shock aims at cardiocirculatory support by vigorous volume therapy and eventually vasoactive drugs to ensure peripheral oxygen delivery.

Severe hypovolemia and traumatic shock cause a significant reduction in splanchnic blood flow and ischemic injury of the intestinal mucosa $(16,32)$. Shock and hypoperfusion, cause mucosal injury, and result in the subsequent translocation of bacteria and toxins from the gut lumen into the systemic circulation (3). The concept of the reperfusion lesion by generation of oxygen free radicals via the enzyme xanthine oxidase, which has its highest concentration in the villous tip of the intestinal mucosa, has been identified as the key determinant in the process of bacterial and endotoxin translocation $(16,19)$. 
The recognition that gut failure and that of distant organs may be causally related has led to heralding the gut as the "motor" of multiple system organ failure $(8$, 13). Systemic sepsis and late multiple system organ failure are the most frequent, and often fatal complications of trauma and major surgery $(7,12,51)$.

The primary factor rendering patients at risk for developing multiple system organ failure after shock and trauma is the persistence of impaired micro-circulation with its sequelae for cellular and organ function $(6,42)$. As a consequence of prolonged low flow state, associated with massive blood loss and tissue trauma, nutritional blood flow and oxygen delivery are compromised $(29,30)$. The capillaries' lumen becomes narrowed due to swelling of endothelial cells and the adhesion of activated polymorphonuclear leukocytes (PMNL) to the endothelium are phenomena that may completely abolish local flow. In addition, the interaction of PMNL with the venular endothelium is enhanced by the liberation of toxic oxygen species (20) and followed by the release of vasoactive mediators (26), promoting further redistribution of tissue perfusion and impediment of nutritional flow (6, 42).

Microcirculatory failure present during established sepsis is developed and sustained by the direct action of endotoxin and the release of vasoactive mediators (21). Cytokines such as interleukin-1 and interleukin- 6 and tumor necrosis factor are able to elicit many of the systemic effects characteristically seen during endotoxemia $(17,43)$. These cytokines have also recently been shown to occur in the bloodstream as a response to hemorrhage and tissue trauma (14). The ensuing activation of cascade systems and PMNL-endothelial interaction favor a significant redistribution of capillary perfusion within the microvascular network, resulting in a critical overall reduction in nutritional blood flow $(9,42,50)$. Microcirculatory failure is thus regarded as a predominant mechanism for inadequate oxygen extraction, which develops as early as the initial hyperdynamic phase of septic shock $(5,42,48)$.

The hypertonic small-volume treatment with hypertonic saline solutions has been validated in various experimental models of severe hemorrhagic shock and in pre-hospital and emergency room care trials of trauma patients. Data from these papers have demonstrated the efficacy of hypertonic volume therapy in restoring central hemodynamics and in normalizing the affected microcirculation. Hence, prevention of early deaths and late complications, such as sepsis and multiple system organ failure, has stimulated the investigation of the feasibility of this new concept involving volume replacement in sepsis and endotoxic shock.

\section{CONCEPT OF "SMALL-VOLUME RESUSCITATION"}

Experimental data on small-volume resuscitation of dogs subjected to severe hemorrhagic shock, which was lethal in animals treated with isotonic saline, were published in 1980. The authors demonstrated that $7.5 \%$ saline infused in a volume equivalent to only $10 \%$ of the shed blood volume rapidly increased systemic pressure and restored cardiac output, thus allowed $100 \%$ long-term survival of dogs (52).

De Felippe et al., described the hypertonic smallvolume therapy on 12 intensive care patients in hypovolemic shock refractory to conventional treatment. In these patients, the shock state was reserved after intravenous injections of $100-400 \mathrm{ml}$ of $7.5 \%$ sodium chloride - given $50 \mathrm{ml}$ at a time - by a rise in arterial pressure, improvement of urine flow and recovery of consciousness (15).

In the past few years, various research groups developed the novel concept of primary resuscitation by means of hypertonic saline solutions and demonstrated that, even in the presence of a $50 \%$ blood loss, a volume as small as $4 \mathrm{ml} / \mathrm{kg}$ body weight of $7.2 \%-7.5 \%$ sodium chloride is enough to instantaneously restore cardiac output and to significantly increase systemic pressure $(27,30)$. During small-volume resuscitation the hypertonic saline solution is given for $2-5 \mathrm{~min}$ through a peripheral vein; this mode of administration results in a rapid and pronounced increase in the plasma sodium concentration and thereby initiates a steep transmembraneous osmotic gradient. The most important mechanism of action of hypertonic solutions is the instantaneous mobilization of endogenous fluid along the osmotic gradient with an increase intravascular volume $(27,38)$; in addition, direct myocardial stimulation, central nervous system (CNS) stimulation, neurogenic reflex mechanisms, enhanced sympathetic discharge, hormone release, improvement of blood fluidity, re-establishment of spontaneous arteriolar vasomotion, and peripheral arterial vasodilation are involved (27). Most recent studies suggest that the rapid cardiovascular response to hypertonic solutions might be partly mediated by the release of eicosanoids (36).

In severe hypovolemia, bolus infusion of $4 \mathrm{ml} / \mathrm{kg}$ body weight $7.2 \%-7.5 \%$ saline solution has been shown to lead to an increase in plasma volume by $8-12 \mathrm{ml} / \mathrm{kg}$ body weight $(45,49)$. Mazzoni et al., have calculated that, after a $20 \%$ blood loss, $7.5 \%$ saline solution given over $10 \mathrm{sec}$ in an amount equivalent to one-seventh of the actual blood loss, re-establishes normal blood volume within one 
$\min (38)$. These authors ascribe the instantaneous volume effect to the rapid influx of fluid from the microvascular endothelium, red blood cells, and the interstitium.

\section{HYPERTONIC SALINE / DEXTRAN RESUSCITATION}

Several authors have reported the transient response of the cardiovascular system after small-volume resuscitation using exclusively hypertonic sodium chloride (27). In order to preserve the intravascular volume gain, $7.2 \%-7.5 \%$ saline solution has been combined with colloids, i.e., dextran $60 / 70$ or hydroxyethylstarch, to elicit a synergistic effect by increasing plasma osmolality and providing high plasma oncotic pressure $(8,24,27)$. Animal studies have revealed that, compared with hypertonic sodium chloride alone, hypertonic saline $6 \%$ dextran 70 causes only a slightly better initial response, but clearly leads to a more sustained circulatory response and an increased survival $(25,34,49,53)$. Based on original work published by Smith et al. (49), Kramer and co-workers recently reported that hypertonic sodium chloride mixed with $6 \%$ dextran 70 given after severe hemorrhage over two hours restored cardiac output for at least $180 \mathrm{~min}$, which was significantly longer than hypertonic saline solution alone or $6 \%$ dextran 70 in isotonic saline (25).

The concept of applying small volumes of hypertonic saline/dextran solution for primary resuscitation from severe hypovolemia has proven to be effective in a prospectively randomized study of trauma patients. As compared to Ringer's lactate, bolus infusion of $250 \mathrm{ml}$ $7.5 \% \mathrm{NaCl} 4.2 \%$ dextran 70 at the site of the accident resulted in a higher systemic pressure $(49 \mathrm{mmHg}$ vs 19 $\mathrm{mmHg})$ and higher survival rate $(8 / 10$ patients vs $3 / 10$ patients) (22). In an extension of their first study, in 1989 Holcroft et al., reported a study involving 60 trauma patients in a randomized, prospective double-blind trial. The administration of $7.5 \%$ saline/dextran resulted in higher blood pressure when the patients reached the emergency room as compared to Ringer's lactate given in the same amount $(250 \mathrm{ml})$, and followed by conventional fluid therapy. The 30-day-survival rate was significantly higher after small-volume resuscitation using hypertonic saline/dextran (23).

Mattox et al., in 1991, analyzed 359 patients with a mean Injury Severity Score (ISS) of 19, who received either $250 \mathrm{ml} \mathrm{7.5 \%} \mathrm{saline} \mathrm{in} \mathrm{6 \%} \mathrm{dextran} 70$ or Ringer's lactate, followed by conventional therapy. There was no difference in overall survival within the first 24 hours; however, in the subgroup of patients requiring surgery and those with a penetrating injury, hypertonic saline/dextran infusion proved to be superior to Ringer's lactate $(\mathrm{p}<0.02$ and $\mathrm{p}<$ 0.01 , respectively). In addition, there were fewer complications (acute respiratory distress syndrome, renal failure, coagulopathy) than in the standard treatment group (37). The use of hypertonic saline/dextran solutions has proven to be safe in patients, as Holcroft et al. (23), Maningas et al. (35), and Mattox et al. in the USA multicenter trial (37), did not encounter any adverse effects. In particular, no anaphylactoid reactions or dextran-related coagulopathies were observed.

\section{EFFECT OF SMALL-VOLUME RESUSCITATION ON THE MICROCIRCULATION IN TRAUMA AND SHOCK}

Microcirculatory impairment, with its sequelae affecting cellular and organ function, is a challenging factor after primary resuscitation from severe trauma. The persistence of this condition may trigger a systemic inflammatory response and multiple system organ failure. Kramer et al., demonstrated an increase in oxygen consumption in unanesthetized adult sheep resuscitated from severe hemorrhage by $7.5 \%$ saline $6 \%$ dextran 70 in a dose equivalent to $10 \%$ of blood loss (24). In addition, Nakayama et al., described the reversal of cellular abnormalities after hemorrhagic shock in rats (46). These laboratory findings confirm the positive results from the above cited pre-clinical trials, and have received substantial support from recent experimental studies on the effect of small-volume resuscitation with hypertonic solutions on organ and nutritional blood flow $(29,30,33,47)$. Our experimental data previously published, based on studies employing radioactive microspheres in protracted traumatic-hemorrhagic shock with a $50 \%$ blood loss, have demonstrated that nutritional blood flow significantly increases within 5 min of i.v. bolus infusion of only $4 \mathrm{ml} /$ $\mathrm{kg}$ body weight $7.2 \%$ saline, while the peripheral shunt flow remains far below pre-hemorrhage levels (29). The addition of hyperoncotic (10\%) dextran 60 not only prolongs but also significantly enhances the microcirculatory effect of $7.2 \%$ saline alone (Table 1)infusion of $4 \mathrm{ml} / \mathrm{kg}$ body weight of $10 \%$ dextran 60 in $7.2 \%$ saline solution in our experiments completely restored nutritional blood flow in kidney, gastric mucosa, 
TABLE 1

Comparative evaluation of the mechanisms involved in small-volume resuscitation using $7.2 \%-7.5 \%$ saline and $6 \%-12 \%$ dextran $60 / 70$ solution

\begin{tabular}{lcc} 
& $7.2 \%-7.5 \% \mathrm{NaCl}$ & $6 \%-12 \%$ Dextran $60 / 70$ \\
\hline 1. Restoration of plasma volume & +++ & ++ \\
2. Vasodilation & ++ & + \\
3. Myocardial stimulation & ++ & + \\
4. Hemodilution with improvement in blood fluidity & ++ & +++ \\
5. Restoration of spontaneous arteriolarvasomotion & ++ & + \\
6. Reduction of leukocyte/endothelial interaction & 0 & ++ \\
\hline
\end{tabular}

small intestine, colon and pancreas. Despite similar changes of the central hemodynamic parameters (systemic pressure, cardiac output), blood flow to these organs remained significantly lower after hypertonic saline resuscitation without dextran (29).

One reason for the superiority of the hypertonichyperoncotic saline/dextran solution appears to be the high oncotic power and water binding capacity of concentrated dextran solution- the $25 \mathrm{~g}$ dextran infused with, e.g. 250 $\mathrm{ml} 10 \%$ dextran 60 , will have the ability to keep 500-625 $\mathrm{ml}$ water in the intravascular space. This maintains the circulatory effect elicited by the hypertonic saline solution, as compared to the addition of a less concentrated solution, i.e., $6 \%$ dextran 60 , (water binding capacity $300-375 \mathrm{ml} /$ $250 \mathrm{ml} 6 \%$ dextran solution). Furthermore, Bayer and coworkers have recently presented their data on the microcirculatory effects of hypertonic-hyperoncotic dextran solution after ischemia/reperfusion injury in the hamster dorsal skin fold model (4). These authors demonstrated that upon $4 \mathrm{~h}$ ischemia and reperfusion of striated muscle, the number of leukocytes adhering to the

Table 2

Effects of small-volume resuscitation using $7.2 \%-7.5 \%$ saline/dextran solution

\begin{tabular}{ll}
\hline Systemic pressure & $\uparrow$ \\
Cardiac output & $\uparrow \uparrow$ \\
Vascular resistance & $\downarrow$ \\
Nutritional blood flow & $\uparrow \uparrow$ \\
Urinary output & $\uparrow$ \\
Survival rate & $\uparrow$ \\
\hline
\end{tabular}

endothelium of postcapillary venules was significantly reduced over $24 \mathrm{~h}$ postreperfusion after bolus infusion of hypertonic saline/dextran solution, whereas the hypertonic saline alone did not exhibit a significantly protective effect on postischemic leukocyte/endothelial interaction. Based on laboratory investigation on uncontrolled hemorrhage in anesthetized rabbits, hypertonic saline/dextran has been suggested to increase "intrinsic" microvascular reactivity, and thus lead to more efficient cardiodynamic improvement than conventional resuscitation with Ringer's lactate given even at 8.5 times the infusion volume of hypertonic saline/dextran (11).

\section{HYPERTONIC SOLUTIONS IN SEPSIS AND ENDOTOXIN SHOCK}

After the initial experimental work by Velasco and co-workers (52) and the clinical observations of De Felippe et al. on intensive care patients (15), various research groups started to investigate the circulatory effect of hypertonic solutions in standardized animal models of hemorrhagic shock, whereas data on its effect on experimental models of sepsis and endotoxin shock have remained scarce.

The infusion of hypertonic solutions with an osmolality of $2400 \mathrm{mosmol} / \mathrm{kg}$ containing $50 \%$ glucose, insulin and potassium (GIK), is known to improve myocardial performance in septic shock in dogs (10). Mullins and Hudgens reported that a small volume of hypertonic saline $-1.2 \mathrm{ml} / \mathrm{kg}$ of $1080 \mathrm{mmol}$ sodium $/ \mathrm{l}(6.3 \%$ $\mathrm{NaCl}$ solution) given over $90 \mathrm{~min}$. resuscitated dogs in endotoxin shock to the same extent as the identical amount of sodium given as isotonic Ringer's lactate (44). 
Treatment with hypertonic saline was associated with a smaller increase in skin and subcutaneous tissue lymph flow, indicating less interstitial edema formation. Recently, Armistead et al., compared the effect of $10 \mathrm{ml} / \mathrm{kg}$ body weight hydroxyethylstarch (HES 450/0.7) in $0.9 \% \mathrm{NaCI}$ with hydroxyethylstarch in $7.5 \% \mathrm{NaCl}$ given over $30 \mathrm{~min}$ for initial fluid resuscitation in septic shock in dogs (1). Arterial pressure, cardiac filling pressures, cardiac output, stroke volume, oxygen delivery and oxygen consumption reached higher values after the administration of the hypertonic saline/hydroxyethylstarch as compared to isotonic hydroxyethyl starch; however, the fluid requirements during the subsequent $3 \mathrm{~h}$ were not significantly different between the two groups.

Based on the favorable results obtained in our previous studies on small-volume resuscitation from hemorrhagic (30) as well as traumatic-hemorrhagic hypotension (29), we have analyzed the efficacy of hypertonic-hyperoncotic solution in a standardized model of acute porcine endotoxemia. Our model is characterized by a high cardiac output/low peripheral resistance circulatory state during sustained i.v. infusion of endotoxin, with vigorous volume support in order to maintain the normal left ventricular filling pressure (28). In these experiments, $4 \mathrm{ml} / \mathrm{kg}$ body weight of hypertonic $(7.2 \%)$ saline combined with hyperoncotic $(10 \%)$ dextran 60 solution were given as bolus infusion over $2 \mathrm{~min}$ after 30 min of hyperdynamic endotoxemia (31). Small-volume resuscitation with hypertonic saline/dextran solution led to a significantly increase in cardiac index within less than $5 \mathrm{~min}$, while systemic pressure remained unaffected. The hyperdynamic circulatory state was maintained throughout the ensuing $3 \mathrm{~h}$ observation period, during which only a fraction of the amount of conventional $6 \%$ dextran 60 had to be substituted as compared to a control group without preinjection of hypertonic saline/dextran. Systemic oxygen delivery, as well as blood flow to heart, kidneys, and splanchnic organs, remained high (31).

The following mechanisms are responsible for the effects of hypertonic volume therapy in hyperdynamic sepsis and endotoxin shock - i. maintenance of high cardiac output (direct myocardial stimulation; increase in preload); ii. maintenance of peripheral vasodilatation (direct effect of hyperosmolality; volume effect); iii. reduction of tissue edema (shifting tissue water). These three mechanisms promote the restoration of the severely impaired microcirculation.

Furthermore, small-volume resuscitation reduces blood viscosity due to the concurrent hemodilution, thereby improving the fluidity of blood through the capillaries, an effect that is even more pronounced when hypertonic saline is combined with a colloid which itself exhibits positive rheologic properties. The specific action of hypertonic saline resuscitation at the microcirculatory level has been emphasized by Mazzoni and co-workers (38), who concluded from their model analysis on blood volume restoration after hemorrhage, that mobilization of fluid out of the endothelium is most pronounced in those capillaries with swollen endothelium, a condition that is frequently observed after sustained periods of even focal ischemia. This shift of fluid from the endothelium increases the luminal diameter, and thus reduces the hydraulic resistance of capillaries. The same authors demonstrated the reopening of shock-narrowed capillaries upon infusion of $7.5 \% \mathrm{NaCl} 6 \%$ dextran 70 in the tenuissimus muscle of rabbits in hemorrhagic shock (39).

\section{CLINICAL APPLICATION OF SMALL- VOLUME RESUSCITATION}

The promising reports from pre-clinical studies about the efficacy of small-volume resuscitation using hypertonic saline/dextran solutions for primary treatment of severe trauma and hemorrhage $(22,23,35)$, and the potentially favorable operational mechanisms, particularly at the level of the microcirculation, have initiated clinical investigations in intensive care patients (27). Recently, Hannemann and co-workers reported on preliminary data obtained from critically ill patients with sepsis or acute respiratory distress syndrome. The authors demonstrated the efficacy of 2-4 ml/kg body weight of $7.5 \%$ hypertonic saline combined with $6 \%$ hydroxyethylstarch on central hemodynamics and oxygen metabolism (18); at the end of the $15 \mathrm{~min}$ infusion period, the cardiac index had increased, as had pulmonary capillary wedge pressure, mean pulmonary artery pressure, oxygen delivery and oxygen consumption, while peripheral resistance was found to have decreased.

\section{COMMENTS}

The novel concept of small-volume resuscitation using hypertonic solutions has been validated in various experimental models of severe hypovolemia and shock. Data from these experiments have demonstrated the efficacy of hypertonic saline/dextran solution with regard 
to the restoration of central hemodynamics and the normalization of compromised microcirculation. Besides rapid restoration of macrohemodynamics and the prevention of early deaths, small-volume resuscitation particularly aims at the prevention of late complications, such as sepsis and multiple systems organ failure, on the basis of persisting microcirculatory disturbances.

A prospective and randomized multicenter trial in critically ill patients in order to assess the efficacy of hypertonic volume therapy versus conventional fluid treatment in the hyperdynamic state of septic shock is underway.
The novelty of hypertonic saline/dextran resuscitation lies in its operational mechanisms at the microcirculatory level; these include the mobilization of fluid preferentially from swollen endothelium, the reduction of postischemic leukocyte adherence to the endothelium of postcapillary venules, and the restoration of spontaneous arteriolar vasomotion. Reopening of shock-narrowed capillaries and restoration of nutritional blood flow is thus. Before this new concept gains entrance into medical textbooks, however, more detailed information on the positive and perhaps hazardous effects of small-volume resuscitation in patients has to be accumulated.

\section{Resumo}

Introdução: As soluçōes salinas hipertônicas em pequeno volume, aplicadas em "bolo", empregaram-se originalmente no tratamento do choque hemorrágico e traumático grave, demonstrando a rápida restauraçāo hemodinâmica e do fluxo sangüineo orgânico regional. Os mecanismos de açāo são diversos - 1. manutenção do débito cardiaco elevado (estímulo direto do miocárdio; aumento do volume intravascular); 2 . manutenção da vasodilatação arterial periférica (efeito da hiperosmolaridade; aumento do volume plasmático); 3 . reduçāo do edema tecidual (fluxo de liquido do intersticio decorrente do gradiente osmótico). Estes eventos promovem a recuperação da acentuada alteraçāo na microcirculação, que freqüentemente são também observadas na sepse. Material e Métodos: O uso destas soluçōes tem sido objeto de vários estudos em modelos experimentais de endotoxemia hiperdinâmica aguda, entretanto, um maior número de estudos clínicos sāo necessários para melhor compreensão dos efeitos positivos, ou eventualmente deletérios, da utilização das soluções cristalóides hipertônicas em pequeno volume na terapêutica da sepse e falência de múltiplos orgãos. Objetivo: $O$ objetivo deste artigo é analisar 0 conceito do uso de soluçōes hipertônicas e o seu potencial no tratamento da intensa hipovolemia e deterioraçāo da microcirculação, que ocorre na sepse e no choque endotóxico. 


\section{REFERENCES}

1. ARMISTEAD, C.W.; VINCENT, J.L.; PREISER, J.C.; DEBACKER, D. \& MINH, T.L. - Hypertonic saline solutionhetastarch for fluid resuscitation in experimental septic shock. Anesth Analg 69:714-720, 1989.

2. BAKER, C.C. - Epidemiology of trauma: the civilian perspective. Ann Emerg Med 15:1389-1390, 1986.

3. BAKER, J.W.; DEITCH, E.A.; LI, M.; BERG, R.D. \& SPECIAN, R.D. - Hemorrhagic shock induces bacterial translocation from the gut. J Trauma 28:896-906, 1988.

4. BAYER, M.; NOLTE, D.; LEHR, H.A.; KREIMEIER, U. \& MESSMER, K. - Hypertonic-hyperoncotic dextran solution reduces postischemic leukocyte adherence in postcapillary venules. Langenbecks Arch Chir (Suppl) 375-378, 1991.

5. BIHARI, D.J. - Mismatch of the oxygen supply and demand in septic shock In: Vincent JL, Thijs LG (eds) Septic shock. Springer Berlin, pp 143-160 (Update in Intensive Care and Emergency Medicine Vol 4), 1987.

6. BIHARI, D.J. - Multiple organ failure: role of tissue hypoxia. In: Bihari DJ, Cerra FB (eds) Multiple Organ Failure. Society of Critical Care Medicine, Fullerton, pp 25-36, 1989.

7. BONE, R.C.; FISHER, C.J.; CLEMMER, T.P.; SLOTMAN, G.J.; METZ, C.A. \& BALK, R.A. - The methylprednisolone severe sepsis study group Sepsis syndrome: a valid clinical entity. Crit Care Med 17:389-393, 1989.

8. BORDER, J.R.; HASSETT, J.; LaDUCA, J.; SEIBEL, R.; STEINBERG, S.; MILLS, B.; LOSI, P. \& BORDE, D. - The gut origin septic states in blunt multiple trauma (ISS $=40$ ) in the ICU. Ann Surg 206:427-448, 1987.

9. BRIGHAM, K.L. \& MEYRICK, B. - Endotoxin and lung injury. State of the art. Am Rev Respir Dis 133:913-927, 1986.

10. BRONSVELD, W.; VAN LAMBALGEN, A.A.; VAN DEN BOS, G.C.; THIJS, L.G. \& KOOPMAN, P.A. - Effects of glucose-insulin-potassium (GIK) on myocardial blood flow and metabolism in canine endotoxin shock. Circ Shock 13:325-340, 1984.

11. BRUTTIG, S.P.; DISCHER, D.; DOHERTY, T.J.; BORGSTROEM, P. \& ARFORS, K.E. - Hypertonic saline dextran (HSD) improves peripheral microvascular performance following massive uncontrolled hemorrhage. Circ Shock 34:36, 1991.

12. CARMONA, R.; CATALANO, R. \& TRUNKEY, D.D. Septic shock. In: Shires GT (ed) Shock and related problems. Churchill Livingstone, Edinburg, pp 156-177, 1984.

13. CARRICO, C.J.; MEAKINS, J.L.; MARSHALL, J.C.; FRY, D. \& MAIER, R.V. - Multiple organ-failure syndrome. Arch Surg 121:196-208, 1986.

14. CHAUDRY, I.H.; AYALA, A.; ERTEL, W. \& STEPHAN, R.N. - Hemorrhage and resuscitation: immunological aspects (editorial review). Am J Physiol 259:R663-R678, 1990.

15. DE FELIPPE, J. Jr.; TIMONER, J.; VELASCO, I.T. \& LOPES, O.U. - Treatment of refractory hypovolaemic shock by $7.5 \%$ sodium chloride injections. Lancet ii:1002-1004, 1980.

16. DEITCH, E.A.; BRIDGES, W.; MA, L.; BERG, R.; SPECIAN, R.D. \& GRANGER, D.N. - Hemorrhagic shockinduced bacterial translocation: the role of neutrophils and hydroxyl radicals. J Trauma 30:942-952, 1990.

17. FONG, Y.; MOLDAWER, L.L.; SHIRES, G.T. \& LOWRY, S.F. - The biological characteristics of cytokines and their implication in surgical injury. Surg Gynecol Obstet 170:363378, 1990.

18. FREY, L.; KREIMEIER, U.; PACHECO, A. \& MESSMER, K. - Effect of $7.2 \%$ saline $/ 10 \%$ dextran- 60 vs. $7.2 \%$ saline/ $10 \%$ hydroxyethylstarch on macro and microhemodynamics in traumatic-hemorrhagic hypotension. Eur Surg Res 22:297 (Abstract), 1990.

19. GRANGER, D.N.; RUTILI, G. \& McCORD, J.M. Superoxide radicals in feline intestinal ischemia. Gastroenterology 81:22-29, 1981.

20. GRANGER, D.N.; BENOIT, J.N.; SUZUKI, M. \& GRISHAM, M.B. - Leukocyte adherence to venular endothelium during ischemia-reperfusion. Am J Physiol 20:G683-G688, 1989.

21. HACK, C.E. \& THIJS, L.G. - The orchestra of mediators in the pathogenesis of septic shock. In: Vincent JL (ed) Update in Intensive Care and Emergency Medicine. Update 1991. Springer, Berlin Heidelberg New York, pp 233-241, 1991.

22. HOLCROFT, J.W.; VASSAR, M.J.; TURNER, J.E.; DERLET, R.W. \& KRAMER, G.C. - $3 \% \mathrm{NaCI}$ and $7.5 \%$ $\mathrm{NaCI} / \mathrm{Dextran} 70$ in the resuscitation of severely-injured patients. Ann Surg 206:279-286, 1987.

23. HOLCROFT, J.W.; WASSAR, M.J.; PERRY, C.A.; GANNAWAY, W.L. \& KRAMER, G.C. - Perspective on clinical trials for hypertonic saline/dextran solutions for the treatment of traumatic shock. Braz J Med Biol Res 22:291293, 1989.

24. KRAMER, G.C.; PERRON, P.R.; LINDSEY, D.C.; HO, H.S.; GUNTHER, R.A.; BOYLE, W.A. \& HOLCROFT, J.W. Small-volume resuscitation with hypertonic saline dextran solution. Surgery 100:239-247, 1986.

25. KRAMER, G.C.; ENGLISH, T.P.; GUNTHER, R.A. \& HOLCROFT, J.W. - Physiological mechanisms of fluid resuscitation with hyperosmotic hyperoncotic solutions. In: Passmore JC, Reichard SM Reynold DG, Traber DL (eds) Perspectives in Shock Research, Metabolism, Immunonology, Mediators and Models. Alan R Liss, New York, pp 311-320, 1989.

26. KREIMEIER, U. \& FREY, L. - Schock. In: Hierholzer K, Schmidt RF (eds) Pathophysiologie des Menschen. VCH. Winheim, pp 1735-1745, 1991.

27. KREIMEIER, U. \& MESSMER, K. - Small-volume resuscitation. In: Kox WJ, Gamble J (eds) Fluid resuscitation. Bailliere's Clinical Anaesthesiology, vol 2. Bailliere Tindall, London, pp 545-577, 1988.

28. KREIMEIER, U.; YANG, Z. \& MESSMER, K. - The role of fluid replacement in acute endotoxin shock. In: Kox W, Bihari 
D (eds) Shock and the adult respiratory distress syndrome. Springer, Berlin, pp 179-190, 1988.

29. KREIMEIER, U.; BRÜCKNER, U.B. \& NIEMCZYK, S. Hyperosmotic saline dextran for resuscitation from traumatichemorrhagic hypotension: effect on regional blood flow. Circ Shock 32:83-99, 1990.

30. KREIMEIER, U.; BRÜCKNER, U.B.; SCHMIDT, J. \& MESSMER, K. - Instantaneous restoration of regional organ blood flow after severe hemorrhage: effect of small-volume resuscitation with hypertonic-hyperoncotic solutions. J Surg Res 49:493-503, 1990.

31. KREIMEIER, U.; FREY, L.; DENTZ, J.; HERBEL, T. \& MESSMER, K. - Hypertonic saline dextran resuscitation during the initial phase of acute endotoxemia: effect on regional blood flow. Crit Care Med 19:801-809, 1991.

32. KVIETYS, P.R. \& GRANGER, D.N. - Hypoxia: its role in ischemic injury to the intestinal mucosa. In: Marston A, Bulkley GB, Fiddian-Green RG, Haglund UH (eds) Splanchnic ischemia and multiple organ failure. Arnold, London, pp 127-134, 1989.

33. MANINGAS, P.A. - Resuscitation with $7.5 \% \mathrm{NaCI}$ in $6 \%$ dextran-70 during hemorrhagic shock in swine: effects on organ blood flow. Crit Care Med 15:1121-1126, 1987.

34. MANINGAS, P.A.; DE GUZMAN, L.R.; TILLMAN, F.J.; HINSON, C.S.; PRIEGNITZ, K.J.; VOLK, K.A. \& BELLAMY, R.F. - Small-volume infusion of $7.5 \% \mathrm{NaCI}$ in $6 \%$ Dextran 70 for the treatment of severe hemorrhagic shock in swine. Ann Emerg Med 15: 1131-1137, 1986.

35. MANINGAS, P.A.; MATTOX, K.L.; PEPE, P.E.; JONES, R.L.; FELICIANO, D.V. \& BURCH, J.M. - Hypertonic saline-dextran solutions for the prehospital management of traumatic hypotension. Am J Surg 157:528-534, 1989.

36. MARTI-CABRERA, M.; ORTIZ, J.L.; DURA, J.M.; CORTIJO, J.; BARRACHINA, M.D. \& MORCILLO, E. Hemodynamics effects of hyperosmotic mannitol infusion in anaesthetized open-chest dogs: modification by cyclooxygenase inhibition. Res Surg 3:29-33, 1991.

37. MATTOX, K.L.; MANINGAS, P.A.; MOORE, E.E.; MATEER, J.R.; MARX, J.A.; APRAHAMIAN, C.; BURCH, J.M. \& PEPE, P.E. - Prehospital hypertonic saline dextran infusion for post-traumatic hypotension - the USA multicenter trial. Ann Surg 213: 482-491, 1991.

38. MAZZONI, M.C.; BORGSTROEM, P.; ARFORS, K.E. \& INTAGLIETTA, M. - Dynamic fluid redistribution in hyperosmotic resuscitation of hypovolemic hemorrhage. Am J Physiol 255:H629-H637, 1988.

39. MAZZONI, M.C.; BORGSTROEM, P.; INTAGLIETTA, M. \& ARFORS, K.E. - Capillary narrowing in hemorrhagic shock is rectified by hyperosmotic saline-dextran reinfusion. Circ Shock 31:407-418, 1990.

40. McCABE, C.J. - Trauma: an annotated bibliography of the recent literature. Am J Emerg Med 8:446-463, 1990.
41. MESSMER, K.F.W. - Mechanisms of traumatic shock and their consequences. In: Border JR, Allgöwer M, Hansen ST, Jr., Rüedi TP (eds) Blunt multiple trauma - comprehensive pathophysiology and care. Dekker, New York, pp 39-49, 1990.

42. MESSMER, K.; KREIMEIER, U. \& HAMMERSEN, F. Multiple organ failure: clinical implications to macro - and microcirculation. In: Manabe H, Zeifach BW, Messmer K (eds) Microcirculation in circulatory disorders. Springer, Berlin, pp 147-157, 1988.

43. MICHIE, H.R.; MANOGUE, K.R.; SPRIGGS, D.R.; REVHAUG, A.; O'DWYER, S.; DINARELLO, C.A.; GERAMI, A.; WOLF, S.M. \& WILMORE, D.W. - Detection of circulating tumor necrosis factor after endotoxin administration. N Engl J Med 318:1481-1486, 1988.

44. MULLINS, R.J. \& HUDGENS, R.W. - Hypertonic saline resuscitates dogs in endotoxin shock. J Surg Res 43:37-44, 1987.

45. NAKAYAMA, S.; SIBLEY, L.; GUNTHER, R.A.; HOLCROFT, J.W. \& KRAMER, G.C. - Small-volume resuscitation with hypertonic saline $(2,400$ mosm/liter $)$ during hemorrhagic shock. Circ Shock 13:149-159, 1984.

46. NAKAYAMA, S.; KRAMER, G.C.; CARLSEN, R.C. \& HOLCROFT, J.W. - Infusion of very hypertonic saline to bled rats. Membrane potentials and fluid shifts. J Surg Res 38:180-186, 1985.

47. PROUGH, D.S.; WHITLEY, J.M.; TAYLOR, C.L.; DEAL, D.D. \& DeWITT, D.S. - Small-volume resuscitation from hemorrhagic shock in dogs: effects on systemic hemodynamics and systemic blood flow. Crit Care Med 19:364-372, 1991.

48. SHOEMAKER, W.C. - Hemodynamic and oxygen transport patterns in septic shock: physiologic mechanisms and therapeutic implications. In: Sibbald WJ, Sprung CL (eds) Perspectives on sepsis and septic shock. Society of Critical Care Medicine, Fullerton, pp 203-234, 1986.

49. SMITH, G.J.; KRAMER, G.C.; PERRON, P.; NAKAYAMA, S.; GUNTHER, R.A. \& HOLCROFT, J.W. - A comparison of several hypertonic solutions for resuscitation of bled sheep. J Surg Res 39:517-528, 1985.

50. THIJS, L.G. \& GROENEVELD, A.B.J. - The circulatory defect of septic shock. In: Vincent JL, Thijs LG (eds) Septic shock. Springer, Berlin Heidelberg New York, pp 161-178 (Update in Intensive Care and Emergency Medicine, vol 4), 1987.

51. TRUNKEY, D.D. - Trauma. Sci Am 249:20-27, 1983.

52. VELASCO, I.T.; PONTIERI, V.; ROCHA e SILVA, R.M.Jr. \& LOPES, O.U. - Hyperosmotic $\mathrm{NaCl}$ and severe hemorrhagic shock. Am J Physiol 239:664-673, 1990.

53. VELASCO, I.T.; OLIVEIRA, M.A. \& ROCHA e SILVA, M. - A comparison of hyperosmotic and hyperoncotic resuscitation from severe hemorrhagic shock in dogs. Circ Shock 21:338, 1987. 